\title{
Narrativas sobre síndrome de Down no Festival Internacional de Filmes sobre Deficiência Assim Vivemos
}

Ana Cristina Bohrer Gilbert ${ }^{(a)}$

Gilbert ACB. Narratives on Down syndrome in Brazil's International Disability Film Festival Assim Vivemos. Interface (Botucatu). 2017; 21(60):111-21.

Brazil's International Disability Film Festival Assim Vivemos happens every two years in Brazil since 2003. Its purpose is to engage the audience in new perspectives on disability through films, interactive activities, images and institutional discourses. In this paper the author analyzes the films whose central subject is Down syndrome, screened between 2003 and 2013 to explore the narrative construction and the kind of images and meanings that are disseminated at the festival. The empirical material was considered under an ethnographical perspective, and was analyzed using semiotic procedures of isotopic analysis. Three main narrative nuclei were identified following the theoretical developments on disability, being one of them in line with what is considered as 'disability aesthetics'.

Keywords. Film festivals. Disability. Down syndrome. Image. Culture.
O Festival Internacional de Filmes sobre Deficiência Assim Vivemos acontece bienalmente no Brasil desde 2003. Busca engajar a audiência em novas perspectivas sobre deficiência por meio de filmes, atividades interativas, imagens e discursos institucionais. Neste artigo, analisam-se os filmes cujo tema central é a síndrome de Down, exibidos entre 2003 e 2013, com o objetivo de examinar o tipo de construção narrativa e as imagens e os significados sobre pessoas com essa condição que são veiculados no festival. Foram utilizadas estratégias etnográficas no tratamento do material empírico e procedimentos semióticos de leitura isotópica na sua análise. Foram identificados três núcleos narrativos principais que acompanham o desenvolvimento teórico sobre deficiência, sendo que um deles apresenta-se alinhado com o que tem sido denominado de 'estética da deficiência'.

Palavras-chave: Festivais de cinema. Deficiência. Síndrome de Down. Imagem. Cultura. (a) Psicóloga e Psicoterapeuta. Rua Voluntários da Pátria, 190, sala 305, Botafogo Rio de Janeiro, RJ Brasil. 22270-012. ana.cbgilbert@ yahoo.com 


\section{Introdução}

O Festival Internacional de Filmes sobre Deficiência Assim Vivemos acontece bienalmente no Brasil desde 2003, com curadoria e produção de Lara Pozzobon e Gustavo Acioli, da Lavoro Produções, empresa que trabalha com acessibilidade em projetos e produtos culturais. Pioneiro no Brasil, o evento é patrocinado pelo Centro Cultural do Banco do Brasil desde a sua primeira edição, por meio de processo seletivo anual realizado por chamada pública.

O festival surgiu como uma mostra de filmes sobre deficiência que reunia uma seleção das produções exibidas em três edições do festival alemão de mesmo nome - Wie wir leben -, do qual os curadores haviam participado em 2001 como cineastas (com filme sobre deficiência visual), acrescida de produções brasileiras. A mostra recebeu apoio da ABM (Arbeitsgemeinschaft Behinderung und Medien/ Disability and Media Association), organização não governamental responsável pela produção do festival alemão, e, a partir da segunda edição, ganhou identidade autônoma, elaborando seus critérios de seleção de filmes. Sua criação está relacionada a um movimento internacional de fortalecimento de discursos sobre diferença e diversidade em contraposição aos discursos de normalização, que surgiu nos anos 1960 e 1970 no Reino Unido e nos Estados Unidos da América ${ }^{1}$, e que é encampado pelo Brasil a partir da Constituição de 1988. Em decorrência, foram formuladas políticas regulamentando sobre os direitos de pessoas com deficiências, sua integração social e seu acesso a serviços, tais como: a Política Nacional para a Integração da Pessoa Portadora de Deficiência, de 1999, e a Política Nacional de Saúde da Pessoa com Deficiência, de 2002.

Se a intenção inicial do evento era discutir questões relacionadas à acessibilidade de pessoas com deficiências ao entretenimento, valorizando-as como audiência, aos poucos, o festival se configurou como espaço heterotópico, isto é, um espaço onde uma ordem alternativa relacionada aos corpos humanos pode ser vislumbrada ${ }^{2}$. Na acepção de Foucault ${ }^{3}$, heterotopia ${ }^{(b)}$ se refere a espaços relacionados a algum tipo de diferença ontológica e epistemológica, como a deficiência, que desestabilizam formas cotidianas de se olhar o mundo e favorecem o aparecimento de novas narrativas. Deste modo, o festival afirma o seu comprometimento com a produção de novos discursos de verdade ${ }^{5}$ sobre pessoas com deficiências, por meio dos quais elas podem se reconhecer como sujeitos e se relacionar consigo próprias em sua diferença. Pretende exercer o papel político de engajar a audiência em novas perspectivas sobre deficiência, questionando estereótipos e preconceitos, e problematizando a utopia de um corpo normal universal, que é assumido como padrão. Contudo, este não é um processo sem percalços, e a presença implícita de padrões de capacidade considerados como desejáveis acaba por reafirmar aquilo que o festival deseja questionar ${ }^{2}$.

Neste artigo, discute-se os filmes sobre uma das deficiências representadas, a síndrome de Down (SD), exibidos em seis edições do festival, entre 2003-2013. Examina-se o tipo de construção narrativa e as imagens e os significados sobre pessoas com essa condição que são veiculados nos filmes. Busca-se compreender qual abordagem visual é privilegiada, e como as imagens são usadas em enredos que visam suscitar reflexões e questionamentos sobre os corpos humanos.

A escolha pela SD se deu pelo fato de ela ter se tornado, no Brasil, um dos símbolos da diversidade humana, sendo tema de diversas campanhas nos meios de comunicação. É, também, uma das condições genéticas mais frequentes, com incidência de um entre setecentos nascidos vivos ${ }^{6}$, sendo tomada como exemplo, por profissionais de saúde, para explicar sobre riscos e tecnologias de rastreamento e diagnóstico pré-natais. (b) Heterotopia é um termo originalmente médico, referindo-se a um órgão ou tecido que se desenvolveu em posição diferente da usual, sem, contudo, caracterizar uma doença ${ }^{4}$. 
Ao seguir por esta linha investigativa, foram utilizadas estratégias etnográficas no tratamento do material, constituindo o que Haraway ${ }^{7}$ propõe como etnografia textual. Da mesma forma que na etnografia tradicional, a etnografia textual requer uma imersão na realidade investigada, igualmente arriscada e desestabilizadora, uma vez que o pesquisador é sempre parcial, e só pode se aproximar do seu objeto de estudo a partir de uma perspectiva corporificada e localizada ${ }^{7}$. Tais estratégias se referem a um tipo de atitude diante das fontes escolhidas que busca esvaziar-se de concepções apriorísticas e das imagens sobre SD que foram criadas historicamente, para, então, poder perceber outras.

Os filmes foram considerados como textos, ou seja, enunciados com características de autonomia, significação e função integrais, compondo um corpus cujo elemento comum é a SD. Dito de outra forma, o mais importante na análise não foi discutir cada filme individualmente, mas a inter-relação entre eles, a fim de se observar se há um padrão comum de imagens e de narrativas, e quais as mudanças que, porventura, ocorreram nesse padrão durante o período analisado. Assim, ao se falar em filmes sobre SD, não se fala apenas de relatos de vidas individuais, cujas memórias, vivências e afetos são mostrados nos filmes e narrados, também, pelos corpos de quem vive com essa condição. Fala-se, também, de memórias e experiências que se referem a um grupo específico, uma paisagem biológica na política vital contemporânea ${ }^{8}$, que, apesar das particularidades individuais, compartilha aspectos comuns que vão desde as semelhanças somáticas provocadas pela presença de um cromossomo 21 extra até os significados gerados pela proliferação dos discursos.

Após a leitura exaustiva do material, foram usados procedimentos de leitura isotópica para a identificação de categorias de significação idênticas (ou compatíveis) presentes ao longo do texto - as categorias isotópicas $^{9}$-, e que indicam a direção de interpretação do próprio texto ${ }^{10}$. A discussão que se segue é resultado da articulação entre tais categorias e o referencial teórico sobre o tema, com referência a alguns filmes como casos ilustrativos da discussão.

\section{Núcleos narrativos: formas de olhar, sentidos e imagens}

Todos os 16 filmes analisados, à exceção de dois, são documentários de curta ou média duração. O apelo de 'objetividade' que tende a ser associado ao documentário sugere que o filme mostra a realidade 'literal' de pessoas com SD, e não uma representação, resultado de perspectivas parciais traduzidas em roteiro, ângulos, luz, editoração, que acompanham o que se conhece e se pensa sobre a $\mathrm{SD}$ em um determinado momento. Após selecionar 'o que' quer filmar (objeto de interesse), o diretor deve decidir sobre como 'fazê-lo' (distância, foco, ângulo, movimento, ponto de vista utilizado nas tomadas) e como 'apresentá-lo' (edição) ${ }^{11}$. Aquilo que se apresenta ao espectador é resultado dessas escolhas, somado à circunstância de mundo que cerca a produção das imagens e que compõem o que Ramos $^{12}$ denomina de circunstância da tomada.

Argumenta-se que os filmes sobre deficiência (e sobre a SD em particular) trazem um forte aspecto corpóreo, na medida em que as diferenças (ainda que nem sempre explícitas) que se apresentam nos corpos contam por si histórias que acompanham o enredo do filme. Essa visão do corpo do outro produz, em quem vê, efeitos racionais, emocionais e viscerais, capazes de deixar marcas ${ }^{13}$.

Nos filmes, a história que pode ser lida nos corpos individuais carrega memórias coletivas que abarcam desde a nomeação, sob a forma de um diagnóstico, de algo considerado indesejável ${ }^{14}$, até as repercussões desse diagnóstico em novas ordenações biográficas e sociais ${ }^{15}$. No caso da SD, aspectos relacionados à identidade biológica, com referência explícita à categoria diagnóstica, estão presentes em todos os documentários; já nos ficcionais, isso é veiculado implicitamente pelo corpo da personagem, graças à familiaridade do público com os sinais corporais que a definem. Tal presença deixa claro quanto esses aspectos são relevantes para o processo de construção de identidade dessas pessoas. Imagens do cotidiano são bastante exploradas com tomadas longas de atividades de cuidado de si ou da casa, sugerindo uma realidade não 'editada'. O uso de filmes caseiros ou fotografias funciona como registro documental do desenvolvimento da criança com SD, mas, sobretudo, resume, em imagem, os afetos e as sensações vivenciados no processo de descoberta do que significa (con) viver com a SD. 
O aspecto de corporeidade presente nos filmes aponta para a noção de estética da deficiência desenvolvida por Tobin Siebers ${ }^{16}$. O autor discute essa noção inspirado na definição de estética de Alexander Baumgarten (1714-1762), que diz respeito ao estudo "das sensações que certos corpos sentem na presença de outros corpos" (p. 1). Por corpos, Siebers ${ }^{16}$ entende "aquilo que aparece no mundo" (p. 25), sejam corpos humanos e objetos produzidos pelo homem, como esculturas, pinturas e edifícios, sejam animais e objetos da natureza. Ele argumenta que as sensações produzidas são involuntárias, como se esses corpos estabelecessem uma comunicação inconsciente entre si. Tais relações mediadas por afetos constituem a base do que é considerado como belo em determinado momento histórico, e produzem reações nos corpos na presença de outros corpos que explicitam o aspecto material/corpóreo da estética. Para este autor, obras de arte que questionam o modelo de corpo humano, por meio de sua deformação e do uso de diferentes técnicas de representação, revelam afinidades com imagens da deficiência. Suscitam reflexões sobre como sentimentos de prazer e repulsa se entrelaçam com aceitação e rejeição na presença de corpos, especialmente, os humanos, ganhando contornos políticos.

Os filmes apresentam três núcleos narrativos principais: o primeiro deles, o núcleo médico, adota um olhar distanciado que 'conhece sobre'. Remete a um modelo de entendimento da deficiência assentado na medicina, prevalente desde o século XIX até os anos 1970, com suas narrativas sobre corpos considerados anormais, propícios a intervenções ${ }^{1}$. Tal núcleo trata das questões relativas à construção de subjetividade e reorientação da vida a partir do diagnóstico e das estratégias de intervenção, com ênfase no percurso da pessoa com SD (e sua família) do nascimento até o momento atual. O segundo núcleo é o de superação e se articula ao tipo de narrativa produzido pelo modelo social de cunho político que surge nos anos 1970 para questionar o modelo médico. O modelo social separa discapacidades (características biológicas limitantes) e deficiência (algo construído socialmente que é responsável pela exclusão dos indivíduos com diferentes realidades somáticas) ${ }^{1}$, provocando uma dissociação entre as diferentes corporeidades e seu estar-no-mundo. Este segundo núcleo narrativo se contrapõe a percepções sociais preconceituosas, afirma capacidades e prioriza as conquistas alcançadas por essas pessoas, com tendência a focar nos aspectos de igualdade, ainda que em nome da valorização da diferença. E, por fim, o núcleo de corporeidade, cujas narrativas se aproximam daquelas produzidas pelos estudos críticos sobre deficiência, que surgem a partir do final dos anos 1980, desenvolvendo reflexões sobre os dois modelos anteriores. Tais estudos reafirmam a importância da materialidade dos corpos não normativos na constituição do eu, sem, contudo, deixar de considerar a base social do preconceito e da desigualdade ${ }^{1}$. As narrativas de corporeidade deste núcleo reconhecem as marcas somáticas da diferença e delas partem para a construção de um estar-no-mundo mais criativo que permita a coexistência de múltiplos padrões para os corpos humanos fora da polaridade igualdadediferença ou normalidade-deficiência. Tais núcleos não são excludentes e podem se alternar em um mesmo filme; a predominância de um desses núcleos está estreitamente vinculada a diferentes momentos históricos e padrões culturais. Enquanto o núcleo médico prioriza aspectos diacrônicos, ainda que nem sempre de forma cronológica linear, o núcleo de corporeidade é mais focado em aspectos sincrônicos, retratando adultos jovens com SD no que se refere a trabalho, relações afetivas e reprodução. Já o núcleo de superação pode lançar mão dessas duas perspectivas - sincrônica e diacrônica - focando em um momento específico no presente e alternando com a reconstrução do percurso histórico que tornou possível chegar até ele.

A tendência que se observa nas imagens relacionadas aos núcleos médico e de superação é de serem mais distanciadas, localizando a pessoa com SD em interação com seu ambiente. As imagens relacionadas ao núcleo de corporeidade tendem a explorar, de forma contundente, close-ups dos indivíduos - seus corpos, detalhes das mãos ou dos olhos, cujo efeito parece enfatizar o aspecto corporificado da SD e a sua proximidade, sendo capaz de 'tocar' a audiência. O uso das imagens se mostra alinhado com o tipo de perspectiva que cada um desses núcleos prioriza: o médico, mais voltado para um 'conhecimento sobre', o de superação, com foco nas capacidades em comparação com o modelo de normalidade tido como padrão; e o de corporeidade, com valorização das marcas somáticas, o reconhecimento dos limites e contornos da SD e as possibilidades narrativas a partir deles. Tais diferenças no uso das imagens não são absolutas, sendo possível observar a associação das várias perspectivas nos diferentes núcleos narrativos. 
Enredos que priorizam o núcleo médico seguem uma estrutura narrativa básica composta pelo modelo temporal linear equilíbrio-ruptura-equilíbrio ${ }^{17}$, sendo o momento de ruptura o do estabelecimento do diagnóstico. O sentimento de ruptura é exacerbado pela forma como o discurso contemporâneo sobre reprodução é constituído, considerando-a como uma questão de escolha e controle. Isso se torna possível graças à disseminação das tecnologias reprodutivas, incluindo as técnicas de rastreamento e diagnóstico pré-natais e de reprodução assistida, o que reforça a expectativa do bebê perfeitamente normal e transforma qualquer possibilidade fora desse padrão em um 'outro'18. A ocorrência de algo diferente e inesperado traz esse 'outro' do domínio do imaginário para a vida cotidiana, e leva a uma tentativa de nomear esse fenômeno ${ }^{15}$. Nomear não se trata apenas de explicar o desconhecido, receber informações e tomar decisões. Trata-se, sobretudo, de dar sentido àquilo que acontece, de forma a alcançar uma familiaridade, ainda que diferente da anterior ao evento. A presença da SD em um filho, na maioria das vezes facilmente identificável em seus aspectos fenotípicos, é marcada por uma espécie de luto pela perda do filho ideal, do corpo 'normal' ou 'perfeito', da vida como era antes do nascimento. A confirmação do diagnóstico via cariótipo reforça aquilo que se intui ou se sabe clinicamente e, dado seu caráter organizador, estabelece novos marcos para a realidade vivida.

Pela sua força avassaladora, o momento do diagnóstico é recontado por pais nos vários documentários exibidos no festival, e a metáfora da jornada é recorrente para dar a dimensão da intensidade do caminho percorrido pela família. A evocação de fatos ou momentos específicos acontece com frequência sob a forma de flashbacks, com uso de imagens e filmes de produção caseira, além da narração verbal. O momento do diagnóstico carrega um forte impacto emocional, e sua narração é, também, uma oportunidade para explicar sobre a síndrome. Isso permite compartilhar informações e revela o processo de aprendizagem pelo qual a família passou, com incorporação de vocabulário especializado. Também possui um caráter 'libertador' ao assumir a presença de algo até então entendido socialmente como falha, fracasso, imperfeição. Desse modo, o luto experienciado e narrado é individual, mas também coletivo, propiciando um processo de criação que, ao escavar as memórias, permite fabular para dar sentido; permite desarticular narrativas dominantes para construir novas. Esses novos rearranjos nas relações e na produção de narrativas familiares a partir da ocorrência da deficiência compõem o que Ginsburg e Rapp ${ }^{19}$ denominam de novos imaginários de parentesco.

O filme Diagnóstico ${ }^{20}$ exemplifica este primeiro núcleo narrativo. Apesar de ser produzido em 2000, ele traz o conjunto de conhecimentos e percepções sobre SD que vigoravam na Bulgária à época do nascimento de Asparuh Wassilev, em 1979. Naquele momento, o peso do discurso médico, baseado em uma orientação que desestimula o investimento afetivo nessas pessoas devido a taxas menores de sobrevida e à escassa ênfase dada à estimulação precoce, soma-se a concepções religiosas arraigadas na tentativa de encontrar respostas para o que é sentido e vivido como fado e sofrimento. Com o estabelecimento do diagnóstico, começa a construção de uma identidade cujo principal elemento é a marca genética, expressa no cromossomo 21 extra (e, de forma implícita, no excesso de carga gênica).

As primeiras imagens do filme estabelecem o território da SD do qual se fala (Asparuh quando bebê, seu cotidiano, seus interesses, o depoimento dos pais), e correspondem ao que se poderia considerar como sendo da esfera de uma visualidade óptica ${ }^{13}$. A seguir, a câmera percorre uma imagem em preto e branco que, em seu aspecto difuso e indefinido, instiga o espectador a um tipo de olhar que se aproxima de uma visualidade háptica ${ }^{13}$. O que se vê sugere algo do domínio do biológico, mas essa percepção já é resultado do movimento do espectador de lançar mão de um repertório de imagens internalizadas. Aos poucos, percebe-se que se trata da imagem de uma célula vista ao microscópio ${ }^{(c)}$, ferramenta tecnológica que, em seu caráter revelador, participa do processo de produção de subjetividade. Em seguida, o plano se expande e vê-se que a imagem está sendo mostrada em um monitor, acompanhada de explicações dadas pelo médico sobre o número de cromossomos humanos e a presença de um cromossomo extra no par 21 que caracteriza a SD. A imagem ao microscópio retorna e a luz esverdeada que dele emana cede lugar ao verde do olho de Asparuh. A sequência ilustra como o discurso biomédico participa da composição de uma narrativa sobre a pessoa; além disso, faz a conexão entre a marca genética da identidade e a pessoa real, com intermediação da tecnologia científica. 
Laura Marks ${ }^{13}$, em seu livro The skin of the film(d), sobre cinema intercultural, estabelece a diferença entre visualidade óptica e visualidade háptica no tocante à forma como o espectador percebe: a primeira se referindo a uma forma de olhar que pressupõe uma separação entre aquele que vê e o objeto, com valorização da percepção de profundidade (o que leva a uma definição de formas e consequente identificação desse objeto); e, a segunda, a uma forma de visualização que percorre a superfície do objeto e nela se mantém em vez de mergulhar em sua profundidade, priorizando discernir texturas em vez de formas. A visualidade háptica instiga o espectador a se manter na imagem ao invés de ser levado pela narrativa.

Neste ponto, Marks explicita seu alinhamento com a teoria de Gilles Deleuze ${ }^{21,22}$ sobre cinema. ao afirmar que a imagem háptica, que requer, daquele que vê, o uso de recursos internos para completá-la, corresponderia ao que Deleuze ${ }^{21}$ denomina de imagem-tempo; enquanto a imagem óptica se aproximaria da imagem-movimento ${ }^{22}$, a qual contém os elementos necessários para sua compreensão. Ambos os tipos de visualização são indispensáveis ao viver diário (para dirigir um carro, é necessária a visão óptica; para o contato físico de uma relação íntima, a visão háptica é mais apropriada, exemplifica Marks ${ }^{13}$ ) e estão presentes no cinema. Todavia, filmes que enfatizam o tipo de visualidade háptica, como os interculturais, os de orientação feminista e póscolonial, têm sido associados à veiculação de críticas à visualidade óptica como perspectiva afim à dominação e ao controle, por estabelecer uma distância entre o espectador e o objeto visualizado, resultando em um conhecimento 'sobre' o mesmo, e por negar o caráter corporificado da percepção visual ${ }^{13}$.

$\mathrm{Se}$, no cinema intercultural, imagens hápticas, cujo significado é pouco claro, são usadas para suscitar a memória dos sentidos, de forma a representarem experiências resultantes de um deslocamento cultural traumático que não podem ser lembradas ou verbalizadas ${ }^{13}$; nos filmes sobre deficiência, elas sugerem uma incerteza ligada a um aspecto de identidade que, apesar de estar dado no corpo, apresenta-se como desconhecido. Esse tipo de imagem é capaz de salientar a materialidade da SD e do aspecto corpóreo de Asparuh, apresentando uma afinidade com o núcleo de corporeidade.

A descoberta do esporte serve como estímulo vital para Asparuh. Sua dedicação o leva a participar das Olimpíadas Especiais, com excelentes resultados. No entanto, apesar do destaque, ele não consegue completar os estudos nem realizar seu sonho de ingressar na Academia de Desportos da Bulgária. O filme termina nesse impasse, na sensação de desperdício de vida que é compartilhada pelos pais e pelo próprio Asparuh. Então, a mesma imagem dos cromossomos no monitor regressa na cena final do filme. Ao mesmo tempo em que representa o $\mathrm{fa}(\mathrm{r})$ do que Asparuh carrega, parece recuperar a mesma incerteza sugerida no início do filme: incerteza quanto ao futuro e quanto ao lidar com pessoas com SD de forma mais criativa.

O núcleo narrativo de superação tem como personagem principal o herói e suas conquistas. De modo geral, os filmes com esse tipo de enredo contêm elementos do núcleo narrativo médico que, como já apontado, são importantes na produção de subjetividade. Todavia, a ênfase é colocada na capacidade de superação das dificuldades (e da própria deficiência), diluindo o aspecto de diferença (de ser 'outro') enquanto condição de imperfeição, e exaltando as conquistas que trazem a noção de igualdade (ou de ser o 'mesmo'), em muitos casos, confundida com a igualdade de direitos subjacente aos valores democráticos. Mais do que contar uma história sobre a vida dessas pessoas, o que se observa é a tentativa dessas pessoas de 'performarem' a vida que é (c) Cabe notar que a audiodescrição utilizada no festival desmonta o impacto da incerteza ao anunciar que se trata de uma imagem vista ao microscópio.

(d) Em tradução livre: A pele do filme. 
narrada, ou seja, de construírem para si uma narrativa que é vivida para lograr a aquisição de uma identidade estável e sob controle ${ }^{23,24}$. A mensagem implícita é a de que pessoas com SD são como quaisquer outras, e os relatos traduzem um quadro de sucesso dentro dos parâmetros estabelecidos de normalidade, o que significa que as personagens retratadas se apresentam e se comportam o mais próximo possível desse padrão. O tom narrativo adotado resvala para o paternalismo, sugerindo a ativação de fortes mecanismos de compensação. Conforme mencionado, o enredo da superação surge atrelado a um movimento político que expõe o papel da sociedade no estabelecimento e na manutenção de preconceitos, resultando na exclusão de pessoas com deficiências. Porém, quando a ênfase dada à superação ganha proporções exageradas, acaba reafirmando aquilo que se deseja questionar, isto é, o modelo de normalidade como padrão único para o humano. Em nome da diferença, a presença e a valorização da superação trazem o risco de invisibilidade, seja de necessidades diferenciadas, seja da própria pessoa com SD em prol da vitória de uma expectativa social.

A produção canadense Um sonho possíve ${ }^{25}$ é um exemplo do núcleo narrativo de superação, e conta a história de Andrea Friedman, de 26 anos. Logo no início, uma voz em off descreve Andrea e sua vida "de causar inveja a qualquer moça" : considerada uma atriz de sucesso, divide sua vida profissional entre participações em filmes como convidada e o trabalho em um escritório de advocacia. Vive sozinha em Los Angeles, dirige seu próprio carro e passa as noites com amigos ou com o namorado em passeios junto ao mar.

O filme conjuga dois núcleos narrativos: o médico e o de superação. O primeiro narra em detalhes o choque do diagnóstico, a mesma orientação narrada no filme anterior de não investir afetivamente na criança, e todas as escolhas e os percalços pelos quais sua família passou para educá-la e para criar uma forma própria de lidar com o desconhecido. Porém, considera-se que o núcleo de superação é mais central, uma vez que a ênfase é dada à descoberta, incentivo e comprovação das capacidades de Andrea, emoldurada pelo conjunto heroico de valores, característico da sociedade norte-americana. Os pais são os narradores principais e seus discursos apresentam-se ambíguos, ora valorizando Andrea em suas capacidades e limitações, ora explicitando expectativas de uma normalidade 'diferenciada', quer dizer, uma normalidade que apenas levaria um pouco mais de tempo a ser alcançada. A exaltação da "vida invejável" só tem sentido a posteriori, diante do 'sucesso' alcançado por Andrea. Contribui para reduzir a corporeidade da síndrome, uma vez que a medida do sucesso é o padrão de capacidades vinculado à normalidade. Desta forma, cria-se uma imagem coesa de Andrea, reduzindo o sentimento de fragmentação, instabilidade e multiplicidade que a SD (e a deficiência em geral) é capaz de suscitar. Contudo, o esforço de unificação, manifesto por meio de significados naturalizados que contemplam sua disposição afetiva e otimista e seu caráter puro, quase divino, apresenta brechas que ficam claras diante da inegável sensação de frustração de Andrea ao se perceber diferente da normalidade e do seu desejo de não ter a síndrome se the fosse dado escolher.

O terceiro núcleo narrativo, o de corporeidade, privilegia uma perspectiva sincrônica na vida de pessoas com SD. Mais do que provar capacidades, estes filmes reconhecem a diferença trazida pela SD, com a constatação de aspectos de luto necessários à construção de possibilidades criativas de estar-no-mundo, sem que isso signifique impor um regime de comparação e competição com um modelo de normalidade predefinido. Os enredos buscam potencializar qualidades, tais como, meticulosidade, compromisso, cuidado e capacidade de imitação, consideradas comuns a essas pessoas, no sentido de promover a sua inserção como adultos no mercado de trabalho e na sociedade.

Um monte de $\operatorname{coisas}^{26}$ é um filme suíço que exemplifica este núcleo narrativo. Trata da vida de Thomas Bouchardy, rapaz com 26 anos que mora com os pais e trabalha como garçom em um restaurante. Como produção com enredo predominantemente de corporeidade, o filme prioriza a materialidade do objeto/sujeito cinematográfico por meio de elementos táteis, imagéticos e sonoros.

O primeiro aspecto que chama a atenção são as imagens que simulam o uso de película (monocromática), apontando para a materialidade do próprio filme enquanto objeto físico. O aspecto granulado da imagem, que remete a uma produção antiga, traz um aspecto tátil, sugerindo textura.

Um segundo aspecto diz respeito ao modo como a câmera se aproxima do rapaz, sendo recorrente a opção por recortes fechados do seu corpo -rosto, olhos, mãos - ou por detalhes, como o expelir da fumaça do cigarro. Quando Thomas, com um ar divertido após correr muito, lambe a secreção 
que escorre do nariz, a sequência aponta para a quebra no padrão 'adequado' de comportamento público, explicitando uma forma de 'vazamento' literal (ainda que não tão drástico quanto urinar ou evacuar, passível de acontecer em outras deficiências) mas, sobretudo, figurativo ${ }^{24}$, que é associado aos corpos com deficiências em contraposição ao corpo normal, considerado como sob controle, intacto e fechado ${ }^{27,28}$. Com esse tipo de enquadramento e de imagem, a presença corpórea de Thomas é constantemente sublinhada.

O sentido da audição também é ativado pelo filme de forma a reforçar a presença corporal: seja pelo registro da respiração do rapaz, quase sempre audível (o que remete a possíveis problemas do sistema respiratório, frequentes em pessoas com SD), e que ocupa os momentos de silêncio, dandoIhes ritmo, o ritmo de Thomas; seja pelo uso de sons, como o sopro em garrafas, produzindo música, ou a eructação após beber cerveja no gargalo (outra forma de falta de controle 'adequado').

O filme mostra a vida de Thomas com prazeres, dificuldades, frustrações, medos, anseios, sem que haja a necessidade de corrigi-lo, de encobrir suas dificuldades ou de estabelecer metas a serem alcançadas. Ele se diz muito preocupado em passar uma "boa imagem" de pessoas como ele, contrapondo-se àquela passada por pessoas com SD que "se comportam mal". Quais seriam essas imagens que o afetam como parte de um grupo do qual ele se torna porta-voz?

Marks ${ }^{13}$, em seu já citado livro, discute o aspecto de indexicalidade do cinema em geral e do documentário em particular. Porém, a relação indexical com o real por ela enfatizada não diz respeito apenas à questão de o filme ser ou não uma representação fiel do mesmo (especialmente, no caso do documentário, no qual esse aspecto é considerado como central). Refere-se à própria 'marca' que é deixada por um objeto na superfície do filme (ou que é codificada eletronicamente), ou seja, a uma conexão material com aquilo que está diante da câmera para ser filmado (semelhante à marca, ou índice, que a circunstância da tomada deixa em um suporte que 'roda' na câmera' ${ }^{12}$ ). Os argumentos centrais desta autora, ligados aos aspectos metafóricos do título do livro, são os de que o filme possui uma materialidade que o torna "impressionável e condutivo, como a pele"13 (p. xii), e que permeia o contato entre espectador e objeto representado, por meio do qual o filme se torna significativo. Esse contato material se expande pelo fato de o filme ser visto por diversas audiências, em uma espécie de contágio advinda dessa ideia de materialidade que 'afeta' o espectador, cuja presença, por sua vez, é capaz de 'marcar' o filme. A autora sugere, ainda, que o cinema constitui uma experiência multissensorial, envolvendo outros sentidos além da visão, de forma que certas imagens podem ser consideradas táteis em si, como se o espectador pudesse 'tocá-las' com os olhos.

É interessante notar como essas ideias - que Marks ${ }^{13}$ desdobra e aprofunda em seu livro como uma teoria sensorial de representação aplicada ao cinema intercultural - apresentam afinidades com a estética da deficiência desenvolvida por Siebers ${ }^{16}$, sendo capazes de suscitar novos entendimentos acerca do cinema sobre deficiência. Apesar de Siebers não se referir a um tipo de visualidade háptica nas obras de arte, seu questionamento sobre concepções mais abstratas e idealistas de arte, que tendem a desconsiderar a corporeidade subjacente à estética, encontra aproximação com as ideias de Marks. A estética da deficiência traz uma recusa à hegemonia do corpo saudável, confortavelmente 'ausente' ${ }^{27}$ em seus aspectos implícitos de harmonia, integridade e beleza, considerado como padrão único de definição da estética. Segundo Siebers ${ }^{16}$, a incorporação da deficiência aos padrões estéticos, e, implicitamente, das noções de fragmentação, vazamento e disrupção associadas ao corpo com deficiência, que o colocam em contraste com o corpo individual impenetráve ${ }^{27}$, permite repensar as noções de diferença e de variação dos corpos humanos.

Cabe mencionar que as produções brasileiras, tais como, Do luto à luta ${ }^{29}$, De arteiro a artista: a saga de um menino com síndrome de Down ${ }^{30}$ e Meu olhar diferente sobre as coisas ${ }^{31}$, tendem a seguir a mesma linha que enfatiza o núcleo narrativo de superação. Ainda que incluam elementos do núcleo médico ou temas afins ao núcleo de corporeidade, aliados a imagens mais próximas de uma visualidade háptica, tais produções trazem enredos cuja foco principal é narrar os sucessos dessas pessoas em detrimento das dificuldades, de forma a diluir as diferenças que as separam da normalidade. A predominância desse núcleo nessas produções sugere uma característica cultural que reflete a relutância em conviver com a diferença que cerca os corpos não normativos fora da moldura de normalidade. 


\section{Considerações finais}

De modo geral, observa-se que, nos filmes sobre SD, a tendência é a de organizar a experiência, incluir a pessoa com SD na vida linear rotineira em um processo de acomodação, apesar dos momentos de incerteza quanto ao futuro, ou, mesmo, quanto à identidade dessas pessoas. Neste sentido, os filmes sobre SD contrastam com produções sobre outras deficiências, tão desconcertantes que a vida ordinária, linear e organizada não é possível, nas quais a visualidade háptica é mais explorada para expressar aquilo que não se consegue apreender racionalmente. Contudo, certas fraturas persistem nos filmes sobre SD, como consequência, sobretudo, da presença do déficit cognitivo, e aparecem nas entrelinhas dos discursos ou em visualidades subjacentes. Apontam para os limites da inclusão, ou, talvez, para uma idealização de inclusão que significaria uma diluição da diferença. Desta forma, a tentativa de construir uma imagem única da SD (clara como a categoria diagnóstica) não se sustenta, e o que aparece são múltiplas formas de se ter SD que compartilham - mas vão além de - aspectos comuns.

A oscilação entre a necessidade de igualdade e a marca intransponível da diferença expõe a dificuldade de se encontrarem novos modelos para essas pessoas que levem em consideração formas de vida descoladas do padrão de indivíduo autônomo, racional e coeso, considerado como universal ${ }^{32}$. A busca por autonomia de vida e de movimento, que é pautada por coreografias específicas, contrapõe-se à dependência dos pais ou de outras pessoas, impossibilitando o cumprimento de determinadas expectativas. A ambivalência daí decorrente gera ambiguidade nos discursos, enfraquecendo a mensagem política que a faceta de ativismo, subjacente aos filmes e ao próprio festival, deseja transmitir.

Os vários núcleos narrativos, que coexistem em um mesmo relato, utilizam diferentes estratégias para contar sobre essas vidas. Ainda que as diferenças entre os núcleos sejam significativas, apontando para olhares e perspectivas muitas vezes opostos, o elemento de materialidade é recorrente, seja porque é transmitido intencionalmente pelo enfoque adotado pelo diretor, seja porque a presença dos corpos das pessoas com SD (com suas marcas e contornos) se impõe mesmo em narrativas que se esforçam por esfumaçá-la na normalidade. Neste sentido, a constatação de uma estética da deficiência, como considera Siebers ${ }^{16}$, 'provoca e afeta' o espectador em seus conceitos de belo e adequado; explicita o aspecto disruptivo dessas imagens, e convida o espectador a sustentar o incômodo e o desconcerto diante da SD (e da deficiência em geral), sensações estas capazes de provocar questionamentos e reflexões que permitam desestabilizar a utopia do corpo normal universal. Em seu aspecto disruptivo, não se trata de um corpo 'incluso', que se dilui sendo o 'mesmo' que outros, mas de um corpo 'intruso'33, que afeta, instiga, questiona, desafia e se recusa a mergulhar no isolamento e na unilateralidade da inclusão.

\section{Referências}

1. Goodley D, Hughes B, Davis L. Conclusion: disability and social theory. In: Goodley D, Hughes B, Davis L, editors. Disability and social theory: new developments and directions. New York: Palgrave Macmillan; 2012. p. 308-16.

2. Gilbert ACB. Disability film festivals: biological identity(ies) and heterotopia. In: Tascón S, Wills T, editors. Activist film festivals: towards a political subject. UK: Intellect; 2016 (no prelo).

3. Foucault M. Of other spaces. Diacritics. 1986; 16(1):22-7.

4. Johnson P. Unravelling Foucault's 'different spaces'. Hist Hum Sci. 2006; 19(4):75-90. 
5. Foucault M. História da sexualidade 2: o uso dos prazeres. 11a ed. Rio de Janeiro: Graal; 2006.

6. Fonseca $C T$, Amaral DM, Ribeiro $M G$, Bezerra ICR, Guimarães MM. Insulin resistance in adolescents with Down syndrome: a cross-sectional study. BMC Endocr Disord [Internet BioMed Central]. 2005 [acesso 26 Set 2005]; 5:6. Disponível em: http://www. biomedcentral.com/1472-6823/5/6

7. Haraway DJ. Modest_Witness@Second-Millenium.FemaleMan@ Meets OncoMouse $^{\mathrm{TM}}$. New York: Routledge; 1997.

8. Rose N. The politics of life itself: biomedicine, power, and subjectivity in the twenty-first century. Princeton: Princeton University Press; 2007.

9. Greimas AJ. On meaning: selected writings in semiotic theory. Minneapolis: University of Minnesota Press; 1987

10. Eco $U$. The role of the reader: explorations in the semiotics of texts. Bloomington: Indiana University Press; 1979.

11. Aufderheide P. Documentary film: a very short introduction. Oxford: Oxford University Press; 2007.

12. Ramos FP, organizador. A cicatriz da tomada: documentário, ética e imagem-intensa teoria contemporânea do cinema, v. II. São Paulo: Senac; 2005. p. 159-226.

13. Marks LU. The skin of the film: intercultural cinema, embodiment, and the senses. Durham-London: Duke University Press; 2000.

14. Hacking I. The social construction of what? Cambridge: Harvard University Press; 2000.

15. Jutel A. Putting a name to it: diagnosis in contemporary society. Baltimore: Johns Hopkins University Press; 2011.

16. Siebers T. Disability aesthetics. Ann Arbor: The University of Michigan Press; 2010.

17. Chandler D. Semiotics: the basics. 2nd ed. London: Routledge; 2007.

18. Landsman $\mathrm{GH}$. Reconstructing motherhood and disability in the age of "perfect" babies. New York-London: Routledge; 2009.

19. Ginsburg F, Rapp R. Disability worlds. Annu Rev Anthropol. 2013; 42:4.1-4.16.

20. Diagnóstico [filme]. Direção: Eldora Traykova. Bulgária; 2000. 27'.

21. Deleuze G. Cinema I: the movement-image. London: Blomsbury; 1986.

22. Deleuze G. Cinema II: the time-image. London: Blomsbury; 1989.

23. Allison JMJ. Narrative and time: a phenomenological reconsideration. Text Performance Q. 1994; 14(2):108-25.

24. Lindemann K. 'Cleaning up my (father's) mess: narrative containments of "leaky" masculinities'. Qual Inq. 2010; 16(1):29-38.

25. Um sonho possível [filme]. Direção: Hilary Pryor. Canadá; 2006. 49'.

26. Um monte de coisas [filme]. Direção: Germinal Roaux. Suíça; 2004. 28'.

27. Shildrick $M$. Embodying the monster: encounters with the vulnerable self. LondonThousand Oaks-New Delhi: Sage; 2002.

28. Hughes B. Civilising modernity and the ontological invalidation of disabled people. In: Goodley D, Hughes B, Davis L, editors. Disability and social theory: new developments and directions. New York: Palgrave Macmillan; 2012. p. 17-32.

29. Do luto à luta [filme]. Direção: Evaldo Mocarzel. Brasil; 2004. 76'. 
30. De arteiro a artista: a saga de um menino com síndrome de Down [filme]. Direção: Rodrigo Paglieri. Brasil; 2012. 28'.

31. Meu olhar diferente sobre as coisas [filme]. Direção: Gilca Maria da Silveira. Brasil; 2013. 68'.

32. Gilbert ACB. Vértice do impensável: um estudo de narrativas em síndrome de Down. Rio de Janeiro: Fiocruz; 2012.

33. Lapponi E. Corpo intruso - mapa ferido - manifesto anti-inclusão. 2011 [acesso 14 Set 2013]. Disponível em: http://monologosnamadrugada.blogspot.com.br/2011/11/corpointruso-e-manifesto-anti-inclusao.html

Gilbert ACB. Narrativas sobre síndrome de Down en el Festival Internacional de Películas sobre Deficiencia Assim Vivemos. Interface (Botucatu). 2017; 21(60):111-21.

El Festival Internacional de Películas sobre Deficiencia Assim Vivemos se realiza bienalmente en Brasil desde 2003. Busca involucrar al público en nuevas perspectivas sobre deficiencia por medio de películas, actividades interactivas, imágenes y discursos institucionales. En este artículo se analizan las películas cuyo tema central es el síndrome de Down exhibidas entre 2003 y 2013, con el objetivo de examinar el tipo de construcción narrativa y las imágenes y los significados sobre personas con esa condición difundidos en el festival. Se utilizaron estrategias etnográficas en el tratamiento del material empírico y procedimientos semióticos de lectura isotópica en su análisis. Se identificaron tres nucleos narrativos principales que siguen el desarrollo teórico sobre deficiencia, siendo que uno de ellos se presenta alineado con lo que se ha denominado 'estética de la deficiencia'.

Palabras clave: Festivales de cine. Deficiencia. Síndrome de Down. Imagen. Cultura. 
